\title{
And on the Eighth Day, God Visited a Dental Office
}

\section{Andrew Tanchyk}

General Dentist, East Brunswick, USA

*Corresponding author: Andrew Tanchyk, General Dentist, East Brunswick, USA, E-mail: tanch@netzero.net

Rec Date: July 15, 2016; Acc Date: July 18, 2016; Pub Date: July 22, 2016

Copyright: ( 2016 Tanchyk A. This is an open-access article distributed under the terms of the Creative Commons Attribution License, which permits unrestricted use, distribution, and reproduction in any medium, provided the original author and source are credited.

\section{Dental Office}

It was Monday morning and that was tough enough, I thought, to explain the strange look on my receptionist's face. "Doctor", she said, "there's a walk-in emergency and I thought you should look at this". She handed me the health history. It was blank, except for the space for the patient's name. It said, "God".

My receptionist whispered, "He says if it's easier for you, to call him Frank. "Like I said: Monday morning. I had her seat the character, and then entered the room. Sitting in the chair was a grungy looking teenager with a hoodie, sneakers and jeans. Well, I was a wise guy as a teenager too, I thought. But suddenly the door slammed behind me; there was a clap of thunder, a flash of lightning, and my whole life flashed before my eyes.

I was shaking now, tried to catch my breath and said, "I'm going to sit down, would you mind, uh, Frank, or should I kneel?" HE replied, "Sit. I didn't want to scare you, but let's get to the point of why I'm here. Now, I want you to smooth a tooth for me. When I'm reincarnated like this, stuff happens and this morning I chipped my upper right first molar on a damn bagel. I could think it smooth, but it occurred to me that I should check on you dentists. I regularly do personal appearances and revelations to you people - saints, mystics, and poets But I also like to appear to average people. Haven't done a dentist yet. And you're an average one."

I scrunched my face and said, "When you say average..." "I mean average," HE said sternly, "You think you're a hotshot. All humans do. Your old man, Adam, was like that, and I kicked his tail out of Eden for it. You could be like my angels, but look at your souls. What a mess!"

I hadn't ever been this nervous, not since my first occlusal restoration in dental school, or that tax audit. I put on my gloves and facemask, and put a bib on HIM. I positioned HIM and was about to say, "Open wide", when HE said, "Hold on, aren't you forgetting something?"

I stuttered through the facemask, "Well, come to think of it, there are a lot of things ... What the meaning of life is? What is truth? Who killed JFK? What about area 51? And any prophetic insight into the winning World Series and Super bowl teams, and Powerball numbers?

"No! You forgot to discuss the fee for smoothing my tooth, first", HE said authoritatively.

I was now sweating, blushing, breathing heavy and stuttered, "Well, uh, there's no fee, that is, it's a courtesy, an honor, an offering ..."

HE was wrathful now. "Do you take me for a hustler or the entitlement type?"

I was getting some confidence now and said, "Let's make it sixty bucks. The UCR fee. Not that you are usual, customary or, well, I'm sure you are reasonable..."
HE cut me off and replied. "Agreed, Sixty bucks it is. You're getting better. See, you discuss it up front. Bargain if you will. It's uncomfortable for you and the patient, but it's honest. Fee for service. Never did like those damn government socialized plans or corporate insurance schemes. Things don't grow on trees you know...Do you get that symbolism of things on trees?"

I was feeling more like myself now and said, "Yeah, trees, very clever, Frank. Let's take care of that tooth." I turned on the dental light, winked at HIM and said, "Let there be light."

As I grabbed for the handpiece, HE said "Did you sterilize all your instruments today?" HE winked at me, and then said, "Just kidding. I know you did. I know everything. You dentists are a conscientious bunch. Just trying to bust you a little. Give you a little guilt. I don't want to make it too easy for you. It's not supposed to be. Remember what I said about working by the sweat of your brow?"

"You're a funny guy, Frank. Real deep too", I replied, as I smoothed the small cuspal chip. Frank checked it with his tongue and said that it felt great. "Almost as good as I could do myself", He said, winking at me again.

I took another look around his mouth, and then instinctually said, "Good God! Look at all the plaque, calculus, food debris and stain on these teeth! Don't you brush or floss? What a mess!"

HE began sweating, blushing, breathing heavy and stuttered, "I, uh, well, do you know who I am? I'm very busy, important."

I talked authoritatively now, "I always hear this from you VIP types. You're too busy, too important. But they're your teeth, right? And we want these teeth to last a lifetime, or an eternity. But they won't do that without a little time and effort on your part".

HE said nervously, "I feel guilty. Nothing bothered me. I never thought much about it." HE said.

I said sternly, "Well this won't be the first time you took on a malevolent force. Plaque is a silent deceiver. It's always there, waiting for you to have your guard down. And tartar! Give it a chance and it will be fruitful and multiply!"

I handed HIM a mirror and instructed HIM on proper brushing and flossing technique, and the importance of regular recalls. I then cleaned his teeth. (I discussed the fee first). As I finished up I said, "And just remember, only clean the teeth you want to keep. Teeth don't grow on trees; you know ... Do you get that symbolism and irony?"

HE answered, "You're a clever guy, doctor, but can you get that dental light out of my eyes." HE seemed to be anxious to get out of the dental chair for some reason.

"Hold on," I said "Any questions before you leave?" HE replied, "Now that you mention it. Why are you all always so proud, lustful, 
Citation: Tanchyk A (2016) And on the Eighth Day, God Visited a Dental Office. Dentistry 6: e118. doi:10.4172/2161-1122.1000e118

Page 2 of 2

selfish, gluttonous and slothful? What kind of toothpaste do you recommend? And do you prefer waxed or unwaxed floss?"

We discussed all of these profound issues at length. As I shook his hand and said good-bye, I handed him some of my business cards and said, "If you wouldn't mind, Frank, I don't do any advertising. I rely on word of mouth and your word, well!" 